\title{
Effects of anthropic activity dynamics on mangrove ecosystems' degradation in Caracol County - Haiti
}

Johnson Morancy ( $\sim$ johnsonmorancy2017@gmail.com )

Federal University of Amapá: Universidade Federal do Amapa https://orcid.org/0000-0001-7969-4209

Helenilza Ferreira Albuquerque Cunha

Federal University of Amapá: Universidade Federal do Amapa

Alan Cavalcanti da Cunha

Federal University of Amapá: Universidade Federal do Amapa

\section{Research Article}

Keywords: Coastal occupation, environmental vulnerability, socioeconomic activity, The Caribbean

Posted Date: October 18th, 2021

DOI: https://doi.org/10.21203/rs.3.rs-979434/v1

License: (1) This work is licensed under a Creative Commons Attribution 4.0 International License.

Read Full License 


\title{
Effects of anthropic activity dynamics on mangrove ecosystems' degradation in Caracol County - Haiti
}

\begin{abstract}
Anthropization process and climatic changes, mainly deforestation and sea level rise, are factors significantly contributing to the most evident loss of mangrove ecosystems. The aim of our study is to analyze variables related to the effects of the dynamics of human activities closely associated with these ecosystems' degradation. The Geographic Information System tool allowed identifying and comparing soil use and occupation variations based on information provided by 140 randomly chosen participants in Caracol County - Haiti. Interviews were carried out in loco between March and November 2020. Based on results statistically analyzed through multivariate regression tests, the most significant exploratory variable for the mangroves' degradation process $(\mathrm{p}<0.05)$ was "mangrove occupation", regardless of age, sex, schooling, time in the same residence, profession, home distance from the mangrove, landslide events, and risk of floods. We have concluded that distance from home, ecological function, intervention in biodiversity conservation, as well as water-climatic and geo-physical threats are factors closely correlated to mangroves' environmental conservation and management $(\mathrm{p}<0.05)$.
\end{abstract}

Keywords: Coastal occupation, environmental vulnerability, socioeconomic activity, The Caribbean.

\section{Introduction}

Mangrove forests are among the most productive and biologically relevant ecosystems in the world; they form essential habitats for fish and crustaceans, which account for several ecosystem services (Mauricio, Natalie, Mario, \& Francis, 2019). Furthermore, they provide important assets and services that give support to coastal lines' physical stability. Mangrove forests also represent excellent habitats for refuge and nursery of several endemic marine species seen as extremely ecologically valuable, since they absorb significant amount of atmospheric Carbon and, consequently, contribute to reduce the negative effects of climatic changes (Maartje, Maria, Dennis, Jos, \& Sonia, 2018).

Population vulnerability conditions in Latin America and in the Caribbean, for example, and its socioeconomic activities are associated, among other factors, with historical territorial occupation processes, as well as with the existing high population density areas, which result in disordered growth, poverty and social inequality. The political situation in Haiti and its socioeconomic vulnerability conditions are well-known (Szlafsztein, 2020); they worsen and increase the deforestation threat degree. This scenario tends to worsen poverty indices, for they are not 
associated with the high rates of exposure to climatic risks, as well as with lack of land use planning, misery and with low population schooling indices (Singh \& Cohen, 2014).

These are alarming numbers, since only $31 \%$ of Haiti's population has access to basic sanitation; this number drops to $16 \%$ in the countryside. Income inequality is also stagnated based on its Gini coefficient (0.61, since 2001). Thus, the $20 \%$ richest individuals hold more than $64 \%$ of the country's total income, whereas the $20 \%$ poorest individuals only account for $1 \%$ of it. These inequality levels place Haiti among the most unequal countries in Latin America (Lozano-Gracia \& Lozano, 2017).

Human development and the Anthropocene push Haiti down to the $170^{\text {th }}$ position among the 189 countries and territories in the world category of "low human development" - its HDI is 0.510 (PNUD, 2020). These indices are closely correlated to over-exploration of natural resources, which tend to quickly get exhausted, and it would limit any current and future possibility of having communities in these environments to accomplish sustainable development (Hauge, 2018).

Accordingly, Communities in Caracol County - Haiti significantly depend on coastal and marine ecosystems' resources, with emphasis on artisanal and subsistence fishing. These habitats house pelagic fish and corals, as well as benthic resources such as shells, shrimp, sea cucumbers and lobster. These ecosystems are bond to transition ecosystems, with emphasis on floral resources, mainly on vulnerable and explored mangroves for coal production (Global Alliance for Clean Cookstoves, 2017). Figure 1 presents the main profiles and classifications of Caracol Bay (Shamsie, 2014).

Fig. 1 Vegetation cover classification of Caracol County - Haiti, in 2020. 


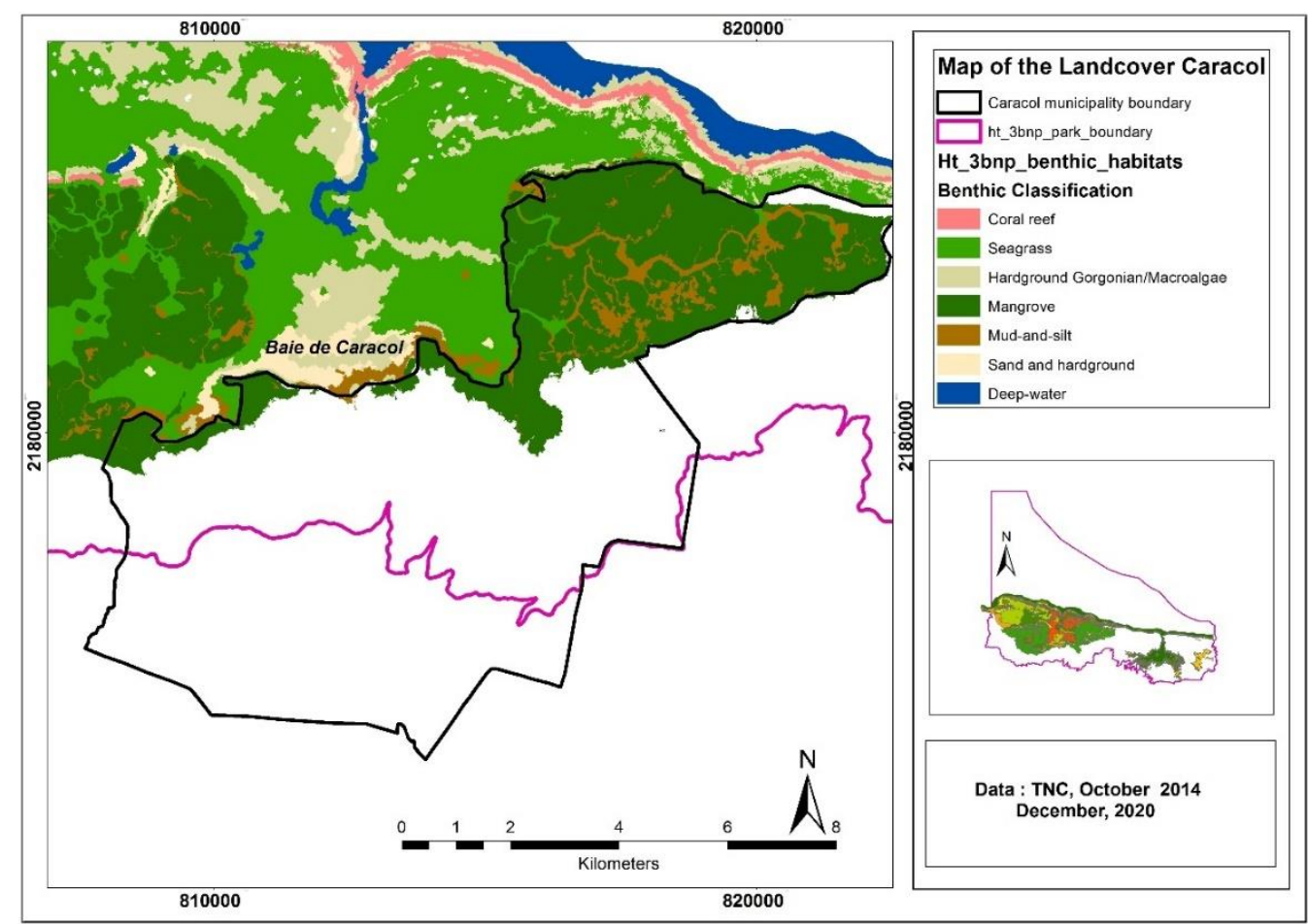

Source: National Geospatial Information Center (CNIGS), December 2020.

The Caribbean Islands are among the ten main biodiversity hotspots; nowadays, they keep some of the highest endemism levels in the world. Caracol region is one of Haiti's most productive coastal and marine areas, although it still has more than 5,000 ha of mangrove forest (Wiener, Gregory, Thomas, \& Daniel, 2013).

This region houses important habitats for several endangered species. For example, there are 301 different identified sessile and vagis benthic organism species, including 149 sponge species, 51 hard coral species, and 43 octocorallia species (Timyan \& Hilaire, 2011). There are also bird species: Anas discors (Blue-winged Teal), Tachybaptus dominicus (Least Grebe), Pelecanus occidentalis (Brown Pelican), Egretta tricolor (Tricolored Heron), Myiarchus stolidus (Stolid Flycatcher), Elaenia fallax Greater Antillean, and Amazona ventralis Hispaniolan Parrot (Luna, Romero-Vidal, Hiraldo, \& Tella, 2018). One of the main threats to birds and terrestrial vertebrates in the region include invasive species, illegal predatory hunt, habitat losses, and waterbodies' pollution and eutrophication (Kramer, et al., 2016).

Its geographic position and geomorphological profile, with relatively plane relief, expose the soil and habitats to the risk of floods, and make them vulnerable to natural hazardous such as sea level rise and extreme climatic events. Despite the natural richness represented by its biodiversity, nowadays, Caracol County has been facing the fast 
degradation of these ecosystems due to bad soil use and occupation, which are associated with inappropriate geographic space. Environmental dynamics in Caracol's coastal bay is truly catastrophic, given the solid waste discarded in both coastal lines and forests (Whitchler-Junior, Roldolf, \& Dieudonné, 2019).

Somehow, communities' socioeconomic vulnerability derives from the worsening of demographic issues (urban and rural migration), mainly from poverty. There are other aggravating factors, such as the population's trend to mainly leave on mangroves' coastal shores (close to food), a fact that accounts for increasing coastal silting rates. This process seems to be affecting the environment's weak resilience ability due to climatic change effects (Pierre A., 2019). Surface water flow at elevated sites in the urban zone transport solid waste and a significant fraction of sediments generated by soil misuse, exposure and occupation (Garcia \& Miralles-Wilhelm, 2017).

Accordingly, we have tested the hypotheses that the degradation of mangroves in Caracol County (Haiti) can be explained either by socio-environmental (anthropic) or natural variables (existing and remaining natural resources). The argumentative basis lies on the fact that both variables are related to mangrove forest and natural resources' predatory uses. The hypotheses are substantiated by the fact that families' main power generation source lies on wood resources combustion; therefore, stopping deforestation under such conditions becomes a crucial matter and great challenge in Haiti (Joseph \& Saffache, 2018).

Simultaneously, such a problem shares the scene with another issue, namely: lack of action by the government to deal with the coal issue in local communities (Blanc, et al., 2019). The excessive cut of native trees and unsustainable agriculture (maize, pea, potatoes, Yam, cassava, banana cultures) have been leading to high deforestation rates, to erosion and vegetal biomass losses, and these factors have remarkable effect on hazardous flood events (Pauleus \& Aide, 2020).

The main goals to test the hypotheses are 1) statistically analyzing locally measured socioeconomic parameters to explain the reasons why populations have occupied and destroyed mangrove forests in Caracol County - Haiti. Based on the hypothesis that the population is putting even its survival and sustainability at risk. The goal was to assess two key variables, namely: a) mangroves' degradation - factor "Fatordegmang" -, and b) mangrove occupation - factor "Ocupmangue". Both factors are based on other 26 independent socioeconomic and socio-environmental variables (age, sex, schooling, income, profession, means to explore natural resources - mainly wood for power generation purposes); 2) determining the effects of the dynamics of anthropic activities and institutional management bond to mangrove ecosystems' degradation in Caracol County - Haiti (geospatial analysis of vegetation distribution in 
mangrove zones). Thus, data of temporal series provided by the National Geospatial Information Center (CNGS) were used to identify and spatially describe soil occupation and to statistically assess the explanatory variables influencing the threats to mangrove ecosystems all over Haiti, mainly in Caracol County.

\section{Materials and Methods}

\section{Study Site}

The research was carried out in Caracol County - Haiti (Fig. 2), which is located within a $75.74 \mathrm{Km}^{2}$ area; its local population comprises 7,714 inhabitants. Thus, field research was conducted to record use and occupation representative variables described by mangrove users and local leaderships' themselves. Independent variables were statistically tested in order to identify the relevant parameters for soil use and occupation by taking into consideration mangroves' disturbances to reason about implementing activities to avoid negative environmental impacts (Kernan, 2019) .

Fig. 2: Study site 1 - Central America, Haiti and Caracol County

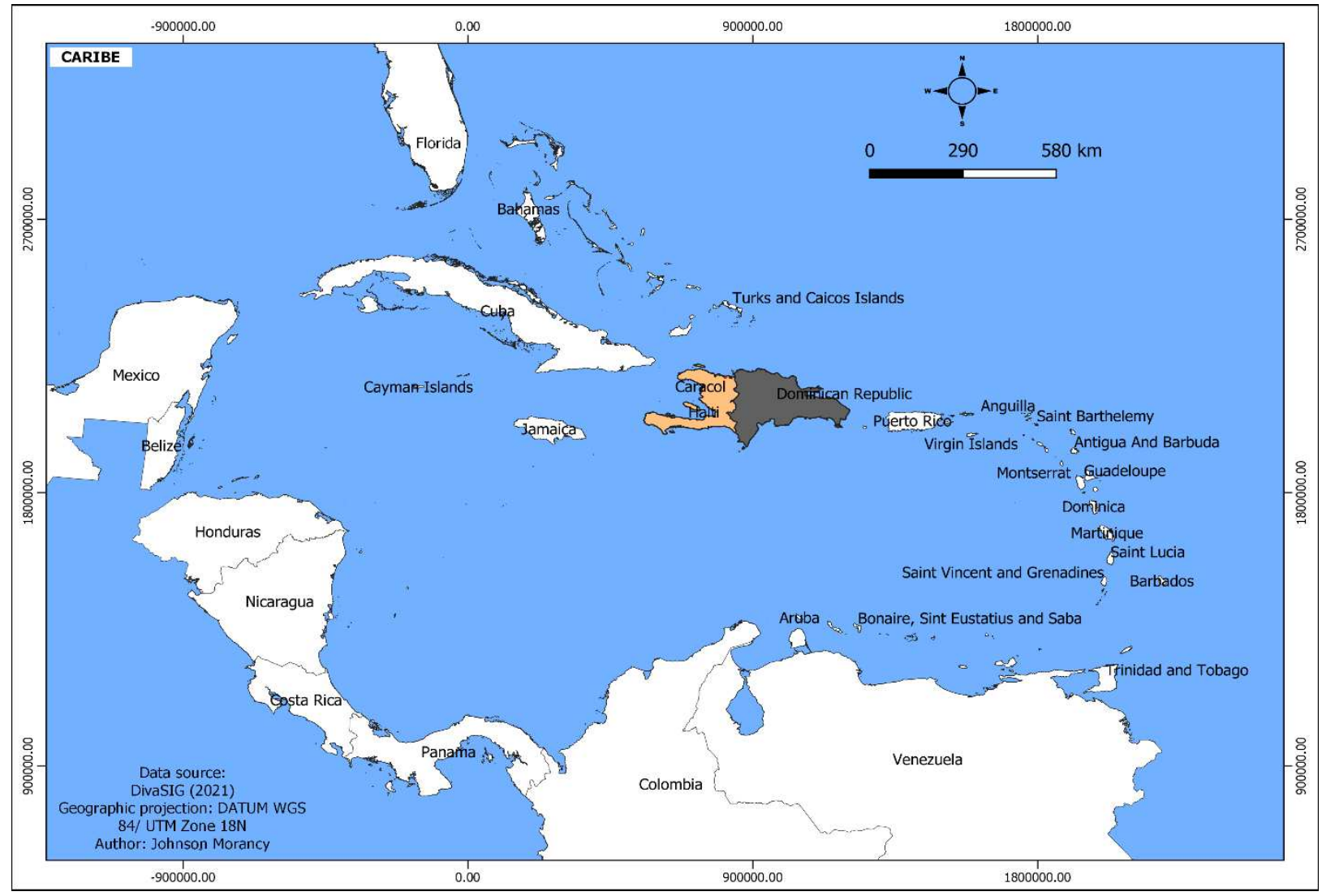

Source: DivaSIG, 2021. 
In total, 28 variables were used; "Factordegmangue" and "Ocupmangue" were taken as dependent variables. For example, factors causing deforestation or natural resources' exploration increase due to residences' location and to their surrounding areas, such as saline sites around mangroves, were used to correlate population growth to urban expansion factors (Atwood, et al., 2017).

\section{Data collection}

The assessed population comprises all mangrove users and local authorities. Information about mangroves' disturbances encompass either mangroves' users or local authorities in Caracol County (Ministério da Saúde, 2020). Users forming the valid sample are the ones who explore at least one of the resources associated with mangrove forest. Local authorities are the ones who account for the proper management of mangroves' ecosystems. The socioeconomic and environmental profiles include fishermen and loggers, saline site explorers, and local autarchies in the municipal administration council (Destro, De, \& Terribile, 2020).

We defined the samples based on the actions of each assessed actor; it was done to assess topics concerning mangrove sites' reduction in comparison to the dynamics of human activities. The method adopted to survey mangrove users and local authorities was based on a random sampling process (Taherdoost, 2016). Questionnaires were locally applied by mangrove users, based on the population sample, which totaled 140 valid respondents in Caracol County - local agents were trained to this research stage. However, interviewees (saline site explorers and local authorities) were randomly picked.

Interviews were carried out from March to November 2020 - interviewees were informed about research aims and identity secrecy, so they could feel safe to share their opinions about mangrove use and management profile in Caracol County. The research project and the format were submitted to and approved by the UNIFAP's Ethics Committee (Plataforma Brasil, Opinion n. 4.203.511).

\section{Research description}

The questionnaire counted on 28 questions, 25 of them were closed and 3 were open; the open questions regarded the participant's general opinion (contributions to and perspectives for mangroves' shared management). Table S1 (supplementary material) describes the questionnaire variables; it was divided into four sections, namely: 1) primary information, regarding residence neighborhood, age, sex, schooling, family origin and income. Monthly 
family income estimate was reported in "Haitian gourdes" (HTG \$) and converted into American dollars (US \$) based on the following Exchange rate 1 USD $=95.0358$ HTG (on December $31^{\text {st }}, 2019$ ); 2 ) anthropogenic factors degrading the mangroves; 3) natural factors that have contributed to degrade the mangroves and that are a threat to them in the assessed county, since individuals live far from mangroves; and 4) identification of local actors who play some role in the county's management and in mangroves' protection.

\section{Soil use and occupation features}

Landcover in Caracol County counts on dense agricultural crops, medium-density agricultural crops, on ecosystem of mangrove, beaches and dunes, savanna, savanna with other vegetation types, dense agroforestry systems, urban areas and saline areas (Fig. 3).

Figure 3: Main vegetation cover in Caracol County

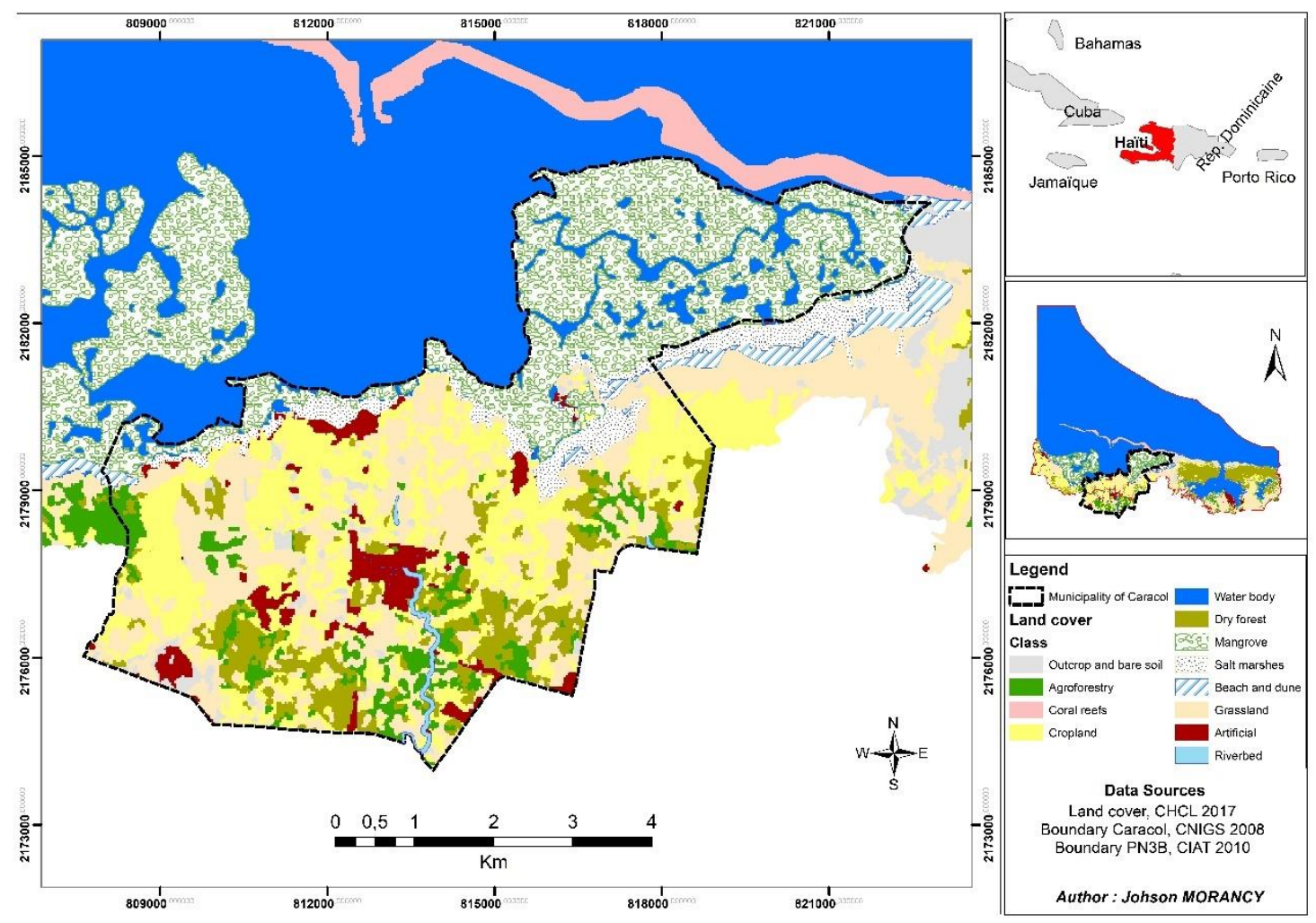

Source: National Geospatial Information Center (CNIGS), 2008.

\section{Statistical analysis}

We have used two basic analysis types: a) simple and multiple regression, based on dependent variables "Ocupemangue" and "Degmangue", and on independent variables: age, time in the current residence, profession, 
family income, distance from home to the mangrove, presence of flooding slopes or floods, significant likelihood of flood threats. Tabulation process and descriptive statistical analysis were carried out in Microsoft Excel. Hypotheses' comparative tests were only conducted in the R-Project tool (data frame of Excel file in "txt"), which generated the data matrix (Kruskal-Wallis regressions and multi-comparative tests) to be subsequently processed at significance level of $<0.05$ (R Core Team, 2016).

\section{Results}

Table 1 lists the significant variables that mostly represented the "reasons" why populations occupy mangrove forest zones (“Ocupmangue”).

Variables in bold highlight the significance of mangroves' occupation significance.

Table 1: Regression tests ran to quantify parameters' variations in mangrove deforestation based on anthropogenic and natural factors in Caracol County - Haiti.

\begin{tabular}{|c|c|c|c|c|}
\hline \multirow{2}{*}{$\begin{array}{l}\text { Parameters } \\
\text { (x) }\end{array}$} & \multicolumn{4}{|c|}{ Regression Tests ( $\mathrm{Y}=$ Ocupmang $) \rightarrow \mathrm{Y}=\mathbf{a}+\mathbf{b x}$} \\
\hline & $\mathbf{A}$ & B & $\mathrm{R}_{\mathrm{ad}(\mathrm{F}, \mathrm{DF})}$ & p-value \\
\hline Age & 0.16 & 0.01 & 0.048 & $0.0083(* *)$ \\
\hline Sex & 0.45 & 0.24 & 0.021 & $0.0599(\cdot)$ \\
\hline Anosesc & 0.90 & -0.04 & 0.025 & $0.0613(\cdot)$ \\
\hline Schooling & ---- & Variant & 0.031 & NS \\
\hline Origcar & 0.61 & -0.06 & -0.08 & NS \\
\hline Tempmor & 0.25 & 0.01 & 0.044 & $0.0112(*)$ \\
\hline Profocup & 0.75 & Variant & 0.28 & $<0.0001(* * *)$ \\
\hline Ativrem & 0.47 & 0.11 & -0.005 & NS \\
\hline Rendfam & 0.21 & 0.002 & 0.162 & $<0.0001(* * *)$ \\
\hline Ocupmangue & ------ & ------ & ------ & ------ \\
\hline Distmangue & 0.78 & -0.001 & 0.0236 & $0.0487(*)$ \\
\hline Ambmangue & ------ & Variant & ------ & NS \\
\hline Afeamb & 0.51 & 0.096 & -0.003 & NS \\
\hline Antrocompma & ----- & Variant & 0.032 & NS \\
\hline DEAPDE & 0.56 & Variant & 0.005 & NS \\
\hline OFME & 0.64 & -0.0946 & -0.005 & NS \\
\hline EIE & 1.11 & -0.57 & 0.044 & $0.0114(*)$ \\
\hline EDE & 0.42 & 1.30 & 0.364 & $<0.0001(* * *)$ \\
\hline
\end{tabular}




\begin{tabular}{lllll} 
SAPI & $\mathbf{1 . 2 5}$ & $\mathbf{- 0 . 7 9}$ & $\mathbf{0 . 1 7}$ & $<\mathbf{0 . 0 0 0 1}(* * *)$ \\
Funactlocal & 0.41 & 0.38 & 0.006 & NS \\
Compartpmang & 0.58 & -0.03 & -0.01 & NS \\
Challenges & 0.82 & Variant & -0.02 & NS \\
Medprotec & 0.47 & Variant & 0.004 & NS \\
Conhogconserv & 1.00 & Variant & 0.012 & NS \\
Protfatornateantr & 0.53 & Variant & -0.013 & NS \\
\hline
\end{tabular}

$(\mathrm{NS}=$ non-significant; if $\mathrm{p}<0.05-$ or close to it - , then, it is not significant (in bold)).

Based on the slope coefficient column (parameter "b"), the only negative values were the ones related to "Distmangue", "SAPI" and "EIE".

Variables that stood out as explanatory for mangroves' occupation, in separate were EDE (36\%), Profocup (28\%), SAPI (16\%) and Income (16\%). EDE and SAP are related to populations' concern with copping with floods and flash floods caused by climatic events that could harm their activities in degraded (or not) mangrove areas. Different professions and/or occupations, as well as the respective income levels (job opportunities and income variations) are relevant additional attractions for mangroves' occupation nowadays and, assumingly, it will be the same, in the future.

Socio-environmental variables "age" and "time living in the same residence" presented positive contribution concerning mangroves' occupation; therefore, they were significant $(\mathrm{p}<0.05)$. In other words, they only explain $4.80 \%$ and $4.38 \%$ of the influence, respectively. Sex and schooling recorded low significance, with explicability of $2.5 \%$ and $2.03 \%$, respectively; these numbers are close to the significance limit $(\mathrm{p} \approx 0.05)$ or have positive contribution. However, they do not satisfactorily explain mangroves' occupation level. The other variables were significant (NS or p $>0.05$ ).

Among all variables related to mangroves' degradation factors, there are the significant ones $(\mathrm{p}<0.05)$, such as distance from the mangroves (Distmangue). However, the distance does not explain much about the mangroves' occupation variation (2.36\%). Other natural and anthropic factors, such as coastal erosion and drought, have been contributing much more to mangroves' occupation and degradation (“Antrocompma”). Experiences with slope landslides (EDE), as well as flood threats (SAPI), and challenges users and local authorities have to face for mangroves' environmental management ("Challenges") emerged as evident threats, since they help explaining mangroves' occupation. 
Variables close to the significant ones ( $\mathrm{p}=0.03$ ) regarding mean family income, can be related to mangroves' degradation, because it is influenced by individuals" paid and economic activities (“Afeamb"); furthermore, it can be associated with flood and flash flood experiences (EIE). The other variables were not significant ( $>0.05)$.

A second analysis was carried out in order to interpret the variables explaining the degradation factor ("Factodegmangue"). Kruskal-Wallis hypotheses' tests worked and complementary analysis in the current evaluation, rather than just mangroves' occupation.

The best interpretations of these tests results were a) residences' distance ("Distmangue") and biodiversity conservation intervention level (“Antrocompma”) are relevant for avoiding mangroves' degradation, since they explain their potential impacts, as well as occupation (interpreted through linear regression based on distance); b) it depends on water-climatic and geophysical factors and threats (climate, time, earthquakes, floods, flash floods, sea level rise, among others). EDE and SAPI were significant in simple linear regression analyses; and c) ecological and managerial functions related to the importance of NGOs and public institutions concerning mangroves' environmental conservation and management were relevant for Kruskal-Wallis tests $(\mathrm{p}<0.05)$.

Table 2: Kruskal-Wallis test applied to assess significant variations in and influence of independent variables on mangroves' degradation factors ("Factodegmangue").

\begin{tabular}{llcl}
\hline \multirow{2}{*}{ Parameters } & \multicolumn{2}{l}{ Kruskal - Wallis $(\mathrm{Y}=$ Factordegmangue $)$} \\
\cline { 2 - 4 } & Df & $\chi^{2}$ & p-value \\
\hline Age & 51 & 51.95 & $0.44(\mathrm{NS})$ \\
Sex & 1 & 1.55 & $0.22(\mathrm{NS})$ \\
Anosesc & 15 & 22.20 & $0.10(\cdot)$ \\
Schooling & 5 & 6.50 & $0.26(\mathrm{NS})$ \\
Origcar & 1 & 0.35 & $0.55(\mathrm{NS})$ \\
Tempmor & 50 & 46.21 & $0.62(\mathrm{NS})$ \\
Profocup & 12 & 14.04 & $0.29(\mathrm{NS})$ \\
Ativrem & 1 & 0.01 & $0.93(\mathrm{NS})$ \\
Rendfam & 43 & 56.56 & $0.08(\cdot)$ \\
Ocupmangue & 3 & 0.50 & $0.92(\mathrm{NS})$
\end{tabular}




\begin{tabular}{llll} 
Distmangue & $\mathbf{8}$ & $\mathbf{2 0 . 0 4}$ & $\mathbf{0 . 0 1 2}(*)$ \\
Ambmangue & 4 & 2.22 & $0.69(\mathrm{NS})$ \\
Afeamb & 1 & 2.77 & $0.09(\cdot)$ \\
Antrocompma & $\mathbf{4}$ & $\mathbf{1 6 . 2 5}$ & $\mathbf{0 . 0 0 3}$ \\
DEAPDE & 8 & 4.03 & $0.85(\mathrm{NS})$ \\
OFME & 1 & 0.45 & $0.46(\mathrm{NS})$ \\
EIE & 1 & 2.86 & $0.09(\cdot)$ \\
EDE & $\mathbf{1}$ & $\mathbf{1 5 . 0 4}$ & $\mathbf{0 . 0 0 0 1}(* * *)$ \\
SAPI & $\mathbf{2}$ & $\mathbf{2 0 . 2 1}$ & $<\mathbf{0 . 0 0 0 1}(* * *)$ \\
Funactlocal & $\mathbf{4}$ & $\mathbf{1 1 . 1 1}$ & $\mathbf{0 . 0 2 5}(* *)$ \\
Compartpmang & 1 & 0.011 & $0.91(\mathrm{NS})$ \\
Challenges & $\mathbf{8}$ & $\mathbf{2 0 . 0 3}$ & $\mathbf{0 . 0 1}(* *)$ \\
Medprotec & 3 & 2.33 & $0.51(\mathrm{NS})$ \\
Conhogconserv & 7 & 7.62 & $0.37(\mathrm{NS})$ \\
Protfatornateantr & 3 & 0.09 & $0.99(\mathrm{NS})$ \\
\hline Significant $(\mathrm{p}<0.05)$ & or close to it (·), and/or highlighted in bold). NS $=$ Non-significant \\
\hline
\end{tabular}

\section{Statistics and Conceptual Flowchart}

A synthetic analysis based either on general anthropic or natural effects was elaborated by using soil use data related to mangroves' management and data related to authorities' accountability for management initiatives, based on field maps and data - general anthropic or natural effects were divided into EDE (36\%) and Profocup (28\%), since both variables were quite relevant in the current study.

If one compares results in Tables 1 and 2 in order to test parameters' variations recorded for soil use and occupation, it is possible stating that degradation was significant. Based on the different approaches (regressions and KruskalWallis), explanatory variables differ from each other in classes. It is so, because the Kruskal-Wallis test takes into account different categories, but the regression does not (global).

Thus, Tables 1 and 2, respectively, are significant for the following variable: time living in the same residence (Tempmor) $-4.38 \%$ and $61.60 \%$. Different scenarios in time living in the same residence variation, as shown in Table 1: EIA explains $11.4 \%$, EDE explain 0.01\%; as for Table 2: EIA explains $9.06 \%$, and EDE explains $0.01 \%$ of variations 
in the impact increased accountability rate recorded for flood events in the most frequent slopes. In other words, they can change mangroves' vegetation areas due to changes in either anthropogenic or natural factors.

Consequently, profession or occupation ("Profocup"), in Table 2, explain 28.56\% of mangroves' degradation variation. Furthermore, if one takes into consideration the current approach about the socioeconomic costs and multiple uses of mangroves' ecosystems, profession or occupation emerged as irrelevant variables for mangroves' degradation (Table 2). Nevertheless, whenever there is categorization (classes - Kruskal-Wallis test), such a significance becomes relevant.

Family income ("Rendfam") only explained $8 \%$ of the degradation (Table 1). With respect to residences' rate and alternatives to migration, these variables only take into account lack of local socioeconomic opportunities to young individuals; and it forces some inhabitants to claim for mangroves' commercial exploration.

When it comes to governance by environmental bureaus given the challenges posed to mangroves' ecosystems management in Caracol County, this factor explains $20 \%$ of influence on mangroves' degradation variation (Table 2, $\mathrm{p}<0.01$ ). A synthesis of analyses about Tables 1 and 2 is shown in the flowchart (Fig. 4). In this case, we have identified that the $1^{\text {st }}$ most relevant dependent variable is mangroves' occupation (“Ocupmangue"), and the $2^{\text {nd }}$ most relevant dependent variable is the mangroves' degradation factor ("Factordmangue"). Both variables basically depend on three sets of factors (which are highlighted by straight blue lines - relevant independent variables; and dashed red lines point out how variables explain variations in the dependent variables). Blue continuous ramifications are represented by a set of variables $\left(\mathrm{R}^{2}{ }_{\mathrm{aj}}\right)$ recording $0.21,0.36$, and 0.38 , respectively. $\mathrm{R}_{\text {aj }}{ }$ represents how numerical or combined factors' values influence Ocupmangue or Factordemange. 


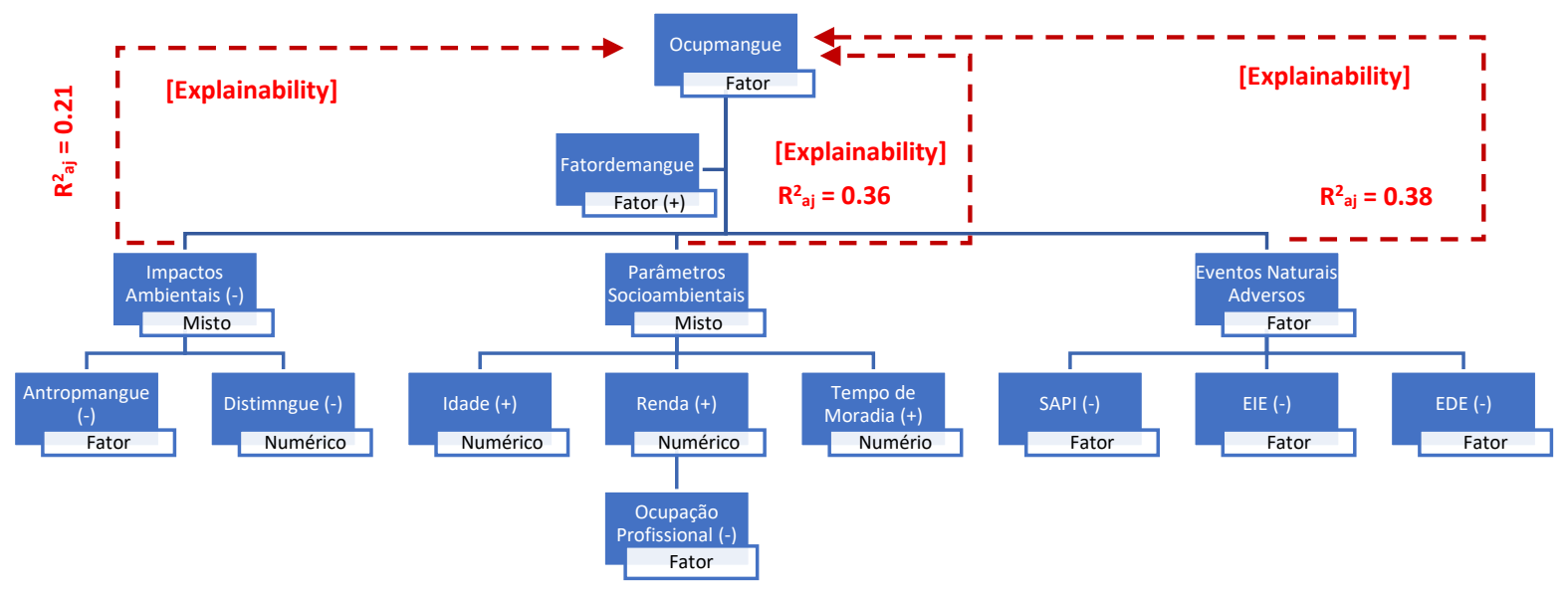

Fig. 4: General flowchart depicting the numerical variables and factors significantly explaining mangroves' occupation and degradation $(\mathrm{p}<0.05)$.

It is important highlighting that $24 \%$ of participants have revealed that mangroves are visibly degraded, but that such a degradation change depending on the location of their residences (urban area). According to $22 \%$ of participants, assumingly, salts' exploration is the main mangroves' environmental degradation factor. In total, $29 \%$ of interviewees believe that solid waste pollutes the ecosystems, and this rate changes depending on the place of their residence.

However, the worst environmental degradation scenario is explained by the uncontrolled use of wood as natural fuel.

\section{Discussion}

\section{Factors related to natural hazardous, socio-economy and the environment}

Natural hazardous and other anthropic factors have been stopping Haiti from changing its economic and human development potential. High and steep mountains cover $63 \%$ of the country's surface, with $20 \%$ slope (or more) and with only $3 \%$ forest coverage; Haiti is one of the most devastated country in the world. Besides, this country is located in the area of hurricanes, not mentioning the swell caused by storms and floods (Glas, Maeyer, Merisier, \& Deruyter, 2020) .

Based on the Global Climatic Change Index published in 2016 by Germanwatch, Haiti is the third country mostly affected by climatic events. Among all Caribbean countries, Haiti is the one suffering with the largest number of hazards per $\mathrm{Km}^{2}$ (based on data by EM-DAT of OFDA/CRED). Therefore, based on the aforementioned numbers, the country has been facing an environmental crisis that is quite worrisome for its citizens. Given its geographic position, the country gets very exposed to such types of climate-related hazardous events, a fact that would have led to annual 
estimated damages and losses close to 2\% of its GDP from 1975 to 2016. Tropical storms and hurricanes back in 2008 have caused losses estimated in $15 \%$ of the country's GDP. The hurricane recorded on January $12^{\text {th }}, 2010$, killed 220,000 people, and it forced the displacement of 1.5 million people and caused destruction equivalent to $120 \%$ of its GDP. Back in October 2016, Matthew Hurricane (category 4 in the Saphir-Simson scale) accounted for wind at speed ranging from 200 to $250 \mathrm{~km} \mathrm{~h}^{-1}$ and caused considerable damage to the Caribbean countries (Azar, 2017).

Based on such a scenario, population growth in Haiti and the ratio of people living in vulnerable urban areas led to substantial increase in the demand for wood and coal. The Ministry of the Environment has estimated that $85 \%$ of the Haitian population depended on biomass energy for domestic use -3.3 million $\mathrm{m}^{3}$ year $^{-1}$ of wood. The conversion of native forests into use resource has been causing deforestation, soil loss, water quality degradation, and socioeconomic instability (Churches, Wampler, Sun, \& Smith, 2014).

Nevertheless, hurricanes and climatic changes also affect the degradation of both mangroves' ecosystems and the environment, as well as biodiversity losses in Caracol County - Haiti (Fig. 4); however, in more general terms, they also affect the rest of the Caribbean. Damage extension is also explained by anthropogenic and natural factors that worsen the conditions in the Caribbean territory (BRL Ingénierie, 2021).

There are approximately 20 swamps in Haiti; they are composed of fresh and salty water, and are mostly interconnected by lakes, lagoons, rivers and lakes (Ndoutoum, 2021). Thus, the current financial support granted to energy and climate-related projects is focused on three priorities set by the government to fight climatic changes: 1) food security, 2) renewable energy sources, and 3) integrated water resources' management. Therefore, hazardous' risk reduction is favored by significant funding, which is directly linked to climatic changes, including agricultural adjustment, reforestation, agroforestry, coastal zone management, training, bio-economy development, institutional reinforcement, mangroves' management, waste protection and management (Gallagher, Perry, Wansem, Kuhl, \& Frapaise, 2019).

According to UN's estimates, and to the Worldmeters' growth model, Haitian population was $10,950,361$ inhabitants in April $3^{\text {rd }}, 2017$ and it will reach 12,578,313 by 2030; and it means increase by $15 \%$ within the estimated time interval. Nowadays, up to 50\% of agro-food products in Haiti are imported, mainly from the Dominican Republic and from the Unites States (USAID, 2016). The United Nations Organization for Food and Agriculture (FAO) estimates that the global agro-food production must rise by $70 \%$ until 2050 . The aim is to fulfil the need of the world's population, which has been growing fast, as well as to restore forest landscapes for ecological purposes and ecosystems' yield (Sprenkle-Hyppolite, Latimer, Young, \& Rice, 2016). FAO (2015) estimated that restoring tropical forests, other forests, and mangroves costs US $\$ 3,450 \mathrm{ha}^{-1}$, US $\$ 2,390$ and US $\$ 2.880 \mathrm{ha}^{-1}$, respectively, on average. It represents the cost-effective relation of 37.3, 10.3, and 26.4 (Walter, 2015).

In hierarchical terms, the main deforestation and soil degradation causes in Haiti are 1) forest and agricultural resources' unsustainable management and exploration, including unsustainable wood extraction (wood biomass for 
power production), since it is the main power source for cooking; and 2) the precariousness of Haitian communities that still face the absurd of having farmers cutting fruit trees to sell its wood. Accordingly, forest ecosystems, mangroves, and coastal and marine ecosystems might be in danger for future generations (Nadeau, Hénault-Ethier, Rony, Michel, \& Monette, 2018). Forest loss is one of the main causes of subsistence means for these populations, since they depend on them - this process can be somehow locally explained, as shown in the flowchart (Fig. 4) and by data in Tables 1 and 2.

Although urbanization in Haiti is the man factor accounting for biodiversity loss, proper projects for, and management of, urban green areas can help keeping significant and valuable biodiversity levels (Exantus, Beaune, \& Cézilly, 2021). Mangroves' management is essential, as evidenced by Haiti’s contribution at national policy level. This policy can be applied to our Case Study about Caracol County - Haiti, which has shown the need of reaching climate targets and sustainable development targets at several dimensions (Kuhl, 2019). General targets for Haiti should be a) integrated water resources and watersheds' management; b) integrated coastal zones' management and infrastructural rehabilitation; c) food security conservation and reinforcement, mainly through bioeconomy development; d) energy transition in order to reduce the dependence on fossil fuel; and e) information, education and awareness (Pierre D. , 2015).

The vulnerability of coastal zones and mean sea level in Haiti have been increasing by $1.8 \mathrm{~mm}^{\text {year }}{ }^{-1}$ (MDE, 2015). Just for comparison, Maimi City (USA) must become one of the metropolis mostly exposed to marine submersion events in years to come, since the combination of tides and swell events mainly contribute to coastal floods. Sea level rise in Miami will lead to great population displacement and migration, as well as to significant damage to properties, infrastructure and the environment. According to the World Resources Institute, local sea level rose 12 inches and it will rise approximately 2 feet $(\approx 60 \mathrm{~cm})$ by 2060 (Islam, Neshkova, \& J., 2017). It is expected that approximately 2 million people will be affected by sea level rise of $1.8 \mathrm{~m}$ by 2100, in Miami (Evans, Hauer, Mishra, 2016). Thus, it is possible assuming that such a threat will be similar in the Caribbean as a whole.

There are several obvious reasons to protect these ecosystems, among them one finds: a) guarantee of proper functioning, since the destruction of a given species can weaken the whole ecosystem; b) keeping its economic relevance (wood, food and medication). Therefore, the ecosystem contributes to the maintenance of the specific diversity composing it, besides being source of coastal stability; c) keeping its role as "carbon absorption pump", which 
acts as fortification against climatic change impacts (hurricanes, tsunamis). Furthermore, it avoids water elevation, which is key element against coil salinization (Calil, Reguero, Zamora, Losada, \& Méndez, 2017).

Based on results in Tables 1 and 2, and on Fig. 4, it is possible observing significant variables that locally explain, for example, perceptions about simultaneous mangroves' occupation and/or degradation. It is so, because the mangrove area is featured by particular vocation to conserve ecosystems' integrity and environmental services (Sardeshpande \& Shackleton, 2020).

Besides, some socioeconomic factors seem to worsen the degradation scenario in mangroves due to severe environmental consequences, to the hard time reestablishing them and to the regeneration limitations of neighbor ecosystems and habitats (Pérez-Ceballos, et al., 2020). Decision-makers can use variable 'profession' to plan integrated management actions based on local initiatives to make the extraction of resources natural to mangroves' ecosystems more effective and sustainable (Carvalho, et al., 2020). On the other hand, they can increase mangroves' vulnerability because of actors' interest in land use and occupation, although they are aware of their harming effect on the environment (Robson \& Klooster, 2018).

Among the aforementioned factors, distance between the residence and the mangrove explains $4.8 \%$ of degradation in mangrove areas (Table 2), with emphasis on solid waste generation. The so-called 'garbage' management has been ineffective and has been generating even more environmental pollution and demand for better management practices, since mangrove forest borders are also confronted by human presence, which indirectly affects forests and often causes their excessive exploration or even their extinction. The anthropogenic dynamics is, therefore, a challenging management element to avoid environmental degradation (Robson \& Klooster, 2018).

Forest fragmentation due to all sorts of anthropogenic disturbances is herein translated by socioeconomic parameters that can cause effective loss of mangroves because of demographic pressure influence. Despite the essential role played by mangroves in the health of the environment, approximately $0.55 \%$ of mangrove area - for each $1 \%$ increase in human population density - is lost for agricultural conversion in one of the biggest mangroves in the world (Turschwell, et al., 2020).

Therefore, forest losses due to anthropic action are a global threat to biodiversity, since they continuously reduce forest species populations. Almost $80 \%$ of primary energy supply in Haiti comes from this source. Accordingly, forests have been severely and dangerously degraded. It has been observed for a long time already, and frequent deforestation cases are induced by excessive wood consumption (Ghilardi, Tarter, \& Bailis, 2018). 
However, the extinction of some species is oftentimes delayed until the last habitat is gone. Mass extinction can be imminent in some tropical countries presenting low forest coverage. Haiti, which has less than $1 \%$ of its original primary forest, is experiencing the mass extinction of its biodiversity (Hedges, Cohen, Timyan, \& Yang, 2018).

The herein assessed variables are also correlated to the likely concern by the population about natural water hydro-climatological events (be them extreme, or not), mainly in areas closer to the coast. The more these events happen, the lower is the trend of mangrove occupation (parameter ' $b$ ' negative - Tables 1 and 2). Variables "Age", "Profocup", "Income" and "EDE" gave positive contribution to mangroves' occupation level (parameter 'b' positive) (Fig. 4). It is important highlighting that, with respect to variable "Profocup variation", based on the results, there are different professions influencing the way mangrove areas are occupied (they are related to liberal professionals, loggers, salt collectors, among others), which is a relevant explanatory factor (Fig. 4, ramification at $R_{\text {aj }}^{2}=0.36$ ). This outcome points out that the profession of different categories explains soil use and occupation by presenting different impact levels on mangrove occupation ('variation in Table 2').

\section{Conclusion}

Mangrove vegetation in Caracol County - Haiti is threatened by significant changes in this ecosystem, to the extent of causing potential decline in sustainability and environmental quality due to vegetal cover suppression. This issue can be attributed to two socio-environmental impact typologies, namely: 1) negative impacts from population pressure, poverty and soil use and occupation; and 2) unsustainable use of natural resources, which is featured by anthropogenic actions associated with, and worsened by, extreme climatic events.

However, different socioeconomic and environmental factors tend to act differently towards impacts over mangrove ecosystems. If these actions remain inappropriate, mangroves tend to extinction, and it will lead to worsened socioeconomic and environmental conditions. However, if these actions are well-oriented, they can lead to integrated and sustainable management actions in Caracol County. Despite actors' extreme poverty socioeconomic situation, it is possible culturally changing consolidated production methods and promoting sustainable mangrove production and protection systems, as well as overcoming pressures that lead to its shallow cut and to its potential extinction, a fact that poses risk to ecosystems and to populations depending on them.

Accordingly, our hypothesis was confirmed. The degradation of Caracol's mangroves, in Haiti, was explained either by socio-environmental or natural variables (or by their interaction). The degradation process experienced by 
their habitats happens based on the combination of (natural) socio-environmental variables and factors, as expressed by its own citizens.

Local policy-makers and decision-makers often face challengers to manage and avoid environmental impacts. Therefore, better political-managerial stability associated with educations actions and concrete awareness about the topic by the population, including proper socio-environmental economic propositions, are essential for this process. It is important shining light on sustainable alternatives that can contribute to mangroves' conservation and benefit socially fairer development solutions. Thus, it is essential taking into account the current socio-environmental context and the population's poverty and misery in the future, so that concrete actions can be put at practice to favor a whole set of actions focused on protecting the local environment, economy and quality of life.

Financial: Federal University of Amapá

conflicts of interest: None

\section{References}

Atwood, T. B., Connolly, R. M., Almahasheer, H., Carnell, P. E., Duarte, C. M., Lewis, C. J., . . Sanders, C. J. (2017). Global patterns in mangrove soil carbon stocks and losses. Nature climate change, 1-8. doi:10.1038/nclimate3326

Azar, M. S. (2017). Cadre de gestion environnementale et sociale (CGES). Ministère de l'Agriculture, des Ressources Naturelles et du Developpement Rural (MARNDR).

Blanc, C. E., Ira, J.-P., Louis, M., Jean-Paul, D., Salomon, S. A., \& Marigo, M. (2019). Sixième rapport national sur la biodiversité d'Haiti. Ministère de 1’Environnement, Haiti.

BRL Ingénierie. (2021). Etude d'Impact Environnemental et Social (EIES). Ministère des Travaux Publics, Transports et Communications (MTPTC).

Calil, J., Reguero, B. G., Zamora, A. R., Losada, I. J., \& Méndez, F. J. (2017). Comparative Coastal Risk Index (CCRI): A multidisciplinary risk index for Latin America and the Caribbean. Plos One, 11, 1-24. doi:http://dx.doi.org/10.1371/journal.pone.0187011

Carvalho, F., Brown, K. A., Gordon, A. D., Yesuf, G. U., Raherilalao, M. J., Raselimanana, A. P., . . Goodman, S. M. (2020). Methods for prioritizing protected areas using individual and aggregate rankings. Environmental Conservation, 47, 113-122. doi:https://doi.org/10.1017/S0376892920000090

Cázares, Y., Vergara, P. M., \& García-Romero, A. (2020). Regeneration of Quercus spp. along interactive forest boundaries in a fragmented peri-urban landscape of Mexico City. Environmental Conservation, 47, 39-45. doi: https://doi.org/10.1017/S037689291900033X

Churches, C. E., Wampler, P. J., Sun, W., \& Smith, A. J. (2014). Evaluation of forest cover estimates for Haiti using supervised classification of Landsat data. International Journal of Applied Earth Observation and Geoinformation, 30, 203-216. doi:http://dx.doi.org/10.1016/j.jag.2014.01.020 
Exantus, J.-M., Beaune, D., \& Cézilly, F. (2021). The relevance of urban agroforestry and urban remnant forest for avian diversity in a densely-populated developing country: The case of Port-au-Prince, Haiti. Urban Forestry \& Urban Greening, 63, 1-9. doi:https://doi.org/10.1016/j.ufug.2021.127217

Gallagher, K. S., Perry, K., Wansem, M. v., Kuhl, L., \& Frapaise, L. (2019). Analysis of International Funding for Haiti's Climate Change Priorities. SSRN, 1-17. doi:http://dx.doi.org/10.2139/ssrn.3333173

Garcia, R., \& Miralles-Wilhelm, F. (2017). Advanced hydraulic and water quality modeling to asses flood and pollution impacts: A case study of the Caracol industrial park in Haiti. Aqua-LAC, 9, 1-14. doi:https://doi.org/10.29104/phi-aqualac/2017-v9-1-01

Ghilardi, A., Tarter, A., \& Bailis, R. (2018). Potential environmental benefits from woodfuel transitions in Haiti: Geospatial scenarios to 2027. Environmental Research Letters, 13, 1-12. doi:https://doi.org/10.1088/17489326/aaa846

Glas, H., Maeyer, D. P., Merisier, S., \& Deruyter, G. (2020). Development of a low-cost methodology for data acquisition and flood risk assessment in the floodplain of the river Moustiques in Haiti. Journal of Flood Risk Management, 13, 1-17. doi:https://doi.org/10.1111/jfr3.12608

Global Alliance for Clean Cookstoves. (2017). Haïti : plan d'action pour la transformation du marché des réchauds et des combustibles.

Hauge, W. I. (2018). Haiti: A Political Economy Analysis. Norwegian Ministry of Foreign Affairs. Retrieved from https://www.prio.org/utility/DownloadFile.ashx?id=1606\&type=publicationfile

Hedges, S. B., Cohen, W. B., Timyan, J., \& Yang, Z. (2018). Haiti's biodiversity threatened by nearly complete loss of primary forest. PNAS, 115, 1-6. doi:10.1073/pnas.1809753115

Islam, M. T., Neshkova, M., \& J., S. (2017). Sea level rise in Miami. ReseachGate, 1-19. doi:10.13140/RG.2.2.32896.74241

Joseph, C., \& Saffache, P. (2018). L'importance des écosystèmes forestiers et les enjeux de la déforestation dans la lutte contre le changement climatique en Haïti : Cas des mangroves du Parc des Trois Baies, des forêts des massifs de la Selle et de la Hotte. Haïti Perspectives, 6, 21-31.

Kernan, B. (2019). Central america regional environment and climate change analysis : final regional tropical forest and biological diversity analysis. United States Agency for International Development.

Kramer, P., M, A., S, S., SM, W., E Freid, G. M., JC, M.-S., . . D, G. (2016). Baseline Ecological Inventory for Three Bays National Park. The Nature Conservancy : Report to the Inter-American.

Kuhl, L. (2019). Synergies between Climate Policies and the Sustainable Development Goals in Haiti. SSRN, 1-17. doi:https://dx.doi.org/10.2139/ssrn.3398352

Lozano-Gracia, N., \& Lozano, M. G. (2017). Haitian cities: action for today with an eye on tomorrow. World bank. Retrieved from https://openknowledge.worldbank.org/handle/10986/29202

Luna, Á., Romero-Vidal, P., Hiraldo, F., \& Tella, J. L. (2018). Cities may save some threatened species but not their ecological functions. PeerJ, 6, 1-22. doi:10.7717/peerj.4908

Maartje, O., Maria, J. S., Dennis, W., Jos, V., \& Sonia, S. (2018). Assessing rehabilitation of managed mangrove ecosystems using high. Estuarine, Coastal and Shelf Science, 211, 238-247. doi:https://doi.org/10.1016/j.ecss.2018.06.020

Mauricio, C.-H., Natalie, B., Mario, R., \& Francis, J. (2019). The mangrove-fishery relationship: A local ecological knowledge perspective. Marine Policy, 1-11. doi:https://doi.org/10.1016/j.marpol.2019.103656

MDE. (2015). Etat d'avancement en termes d'adaptation au changement climatique. Ministère de l'Environnement. 
Nadeau, M. B., Hénault-Ethier, L., Rony, F. J., Michel, G., \& Monette, M. (2018). Restauration des paysages forestiers et agroforestiers jumelée à la valorisation des déchets organiques en Haïti pour le développement durable d'une économie verte résiliente aux changements climatiques. Haïti Perspectives, 6, 1-42.

Ndoutoum, J.-P. (2021). Écosystèmes et zones humides en Francophonie: Préservation, restauration et valorisation pour la survie de la biodiversité. Institut de la Francophonie pour le Developpement Durable.

Pauleus, O., \& Aide, T. M. (2020). Haiti has more forest than previously reported: land change 2000-2015. Peerj, 120. doi:10.7717/peerj.9919

Pérez-Ceballos, R., Zaldívar-Jiménez, A., Canales-Delgadillo, J., López-Adame, H., López-Portillo, J., \& MerinoIbarra, M. (2020). Determining hydrological flow paths to enhance restoration in impaired mangrove wetlands. Plos One, 15, 1-20. doi:https://doi.org/10.1371/journal.pone.0227665

Pierre, A. (2019). Analyse du plan de gestion du parc national des trois baies (Haiti). Université de Liège.

Pierre, D. (2015). Contribution Prévue Déterminée au niveau National. Ministère de l'Environnement.

PNUD. (2020). Rapport sur le développement humain 2020.

Robson, J. P., \& Klooster, D. J. (2018). Migration and a New Landscape of Forest Use and Conservation. Environmental Conservation, 46, 1-8. doi: doi: 10.1017/S0376892918000218

Sardeshpande, M., \& Shackleton, C. (2020). Urban foraging: Land management policy, perspectives, and potential. Plos One, 15, 1-26. doi:https://doi.org/10.1371/journal.pone.0230693

Shamsie, Y. (2014). La construction d'un parc industriel dans l'arrière-pays rural d'Haïti. Quelques observations sur le partenariat État-société et les capacités de l'État. Cahiers des Amériques latines, 75, 79-96. doi:10.4000/cal.3131

Singh, B., \& Cohen, M. J. (2014). Climate Change Resilience: The case of Haiti. OXFAM.

Sprenkle-Hyppolite, S. D., Latimer, A. M., Young, T. P., \& Rice, K. J. (2016). Landscape Factors and Restoration Practices Associated with Initial Reforestation Success in Haiti. ECOLOGICAL RESTORATION, 34, 306316. doi:10.3368/er.34.4.306

Szlafsztein, C. F. (2020). Extreme Natural Events Mitigation: An Analysis of the National Disaster Funds in Latin America. Frontiers in climate, 2, 1-12. doi:http://dx.doi.org/10.3389/fclim.2020.603176

Timyan, J. C., \& Hilaire, J. .. (2011). Les zones clés de la biodiversité d"'Haiti. Comité Interministériel d'Aménagement du Territoire.

Turschwell, M. P., Tulloch, V. J., Sievers, M., Pearson, R. M., Andradi-Brown, D. A., Ahmadia, . . Brown, C. J. (2020). Multi-scale estimation of the effects of pressures and drivers on mangrove forest loss globally. Biological Conservation, 247, 1-11. doi:https://doi.org/10.1016/j.biocon.2020.108637

USAID. (2016). Food assistance fact sheet - Haiti. United States Agency for International Development. doi:https://www.usaid.gov/humanitarian-assistance/haiti

Walter, S. (2015). Sustainable financing for forest and landscape restoration - key messages. Food and Agriculture Organization, Rome.

Whitchler-Junior, J.-P., Roldolf, P. C., \& Dieudonné, p.-L. (2019). Entre activités anthropiques et degradation du littoral haitien: le cas de Caracol. Le national. Retrieved from http://www.lenational.org/post_free.php?elif=1_CONTENUE\%2Fsocietes\&rebmun=3268

Wiener, J., Gregory, C., Thomas, M., \& Daniel, D. (2013). Rapid Ecological Baseline Assessment Lower Trou du Nord River (Caracol Industrial Park). Fondation pour la Protection de la Biodiversité Marine FoProBiM. 
Table 1S: Explanatory variables collected through the questionnaire

\begin{tabular}{ll}
\hline Variable's name & Description \\
\hline ANOSESC & Schooling year; \\
\hline ESCOLAR & Schooling \\
\hline ORIGAR & Origin \\
\hline TEMPOR & Time in the residence \\
\hline PROFCUP & Profession or occupation \\
\hline ATIVREM & Paid activity \\
\hline RENDAM & Monthly family income \\
\hline OCUMANGUE & Mangrove occupation \\
\hline DISTMANGUE & Distance from the mangrove \\
\hline AMBMANGUE & Mangroves' environmental condition \\
\hline AFEAMB & Activity affected by the mangroves \\
\hline ATIVPREJMANG & Activity harming the mangroves \\
\hline FATORDEDMANG & Mangroves' degradation factors; \\
\hline DEAPDE & Anthropic activities in the mangroves \\
\hline OFME & Extinction of animal and plant species due to exploration \\
\hline EIE & Species' migration phenomenon \\
\hline EDE & Flood experience; \\
\hline SAPI & Slope landslide experience \\
\hline FUNACTLOCAL & Threats due to floods \\
\hline COMPARTPMANG & Local actors' functions \\
\hline MEDPROTEC & Behaviors related to mangroves' degradation \\
\hline CONHOGCONSERV & Measures for mangroves' protection \\
\hline PROTFATORNATEANTR & Conservation of mangroves in Caracol's protection area \\
\hline & $\begin{array}{l}\text { Protecting mangroves, among other natural and } \\
\text { anthropogenic factors }\end{array}$ \\
\hline
\end{tabular}

